\title{
Using of light and scanning electron microscopy for pollen morphology of some Epilobium (Onagraceae) taxa and Its taxonomic importance
}

\author{
Birol BAŞER ${ }^{a}$ *'D, Nazli AKAYb iD), Murat KÜRŞATa (iD) \\ a Bitlis Eren University, Department of Biology, 13000, Bitlis, Turkey \\ b Ministry of Family and Social Policies, Disability-Free Living, Care, Rehabilitation and Family Counseling Center, Ahlat, Bitlis, Turkey
}

\section{ART I C LE IN F O}

\section{Article history:}

Received 29 September 2021

Received in revised form 21 October 2021

Accepted 04 November 2021

\section{Keywords:}

Epilobium,

LM,

Onagraceae,

Pollen morphology,

SEM

\begin{abstract}
A B S T R A C T
In this study, pollen morphologies of eleven species of the Epilobium L. genus belonging to Onagraceae family were investigated under light and scanning electron microscopy. Solutions to taxonomic problems of these species were sought with palynological information. The characteristics of the genus Epilobium L. studied as a result of palynological studies are as follows: It has been determined that their pollen grains have tetrad, angulaperturate, 3-zonoporate (rarely 2,4 porate), suboblate and oblate-spheroidal pollen shapes, and have baculate, baculate-rugulate, and rugulate ornamentation.
\end{abstract}

\section{Introduction}

The Onagraceae family having very rich and widespread genera and species are represented by nearly 20 genera and 656 species in the world (Raven, 1962a; Heywood et al., 2007). The genus Epilobium L. (Onagraceae) contains about 200 species that grow in the subarctic, temperate, and subantarctic regions in the world (Walter et al. 2007). Epilobium are mostly herbs. However, few of them are annual or perennial subshrubs. In total, 22 Epilobium species have been reported in Turkey (Okur 2019). Epilobium is a very difficult genus due to its very similar appearance and high probability of hybridization among almost all taxa (Makbul 2008).

Palinomorphology of Onagraceae has been examined by many authors (Erdtman, 1952; Mitroiu, 1963; Ting, 1966; Brown, 1967; Skvarla, et al., 1978-2008; Keri \& Zetter, 1992; Praglowsi et al., 1994; Rowley \& Claugher, 1996; and Rowley \& Skvarla, 2006). Mosquin (1966) examined two subspecies of $E$. angustifolium according to their morphology; E. angustifolium
(C) 2021. Turkish Journal Park Academic. All rights reserved.
L. subsp. circumvagum Mosquin taxon is tetraploid $(\mathrm{n}=36)$ and E. angustifolium L. subsp. angustifolium is diploid $(\mathrm{n}=18)$ and hexaploid $(n=54)$. Tetraploid taxa with three and four pores, and diploid taxa having pollens with three pores are found together. Brown, (1967) stated that in the Epilobieae tribe, which also includes the Epilobium pollen grains are seen as either monads or tetrahedral tetrads. The pollen of tetraploid taxa is larger than the pollen of other taxa whereas, pollen grains with four pores are denser in hexaploid taxa. Punt et al., (2003) comprehensively studied pollen morphology of the Onagraceae from Northwest Europe. Skvarla et al., (2008) examined pollen morphology of Epilobium luteum of Onagraceae belonging to tribe Onagreae. Makbul et al., (2008) studied the anatomical and pollen morphological characters of the genus Epilobium from Northwest Anatolia and reported that anatomical features are more important than palynological features for explaining the variation among these taxa. Skvarla et al., (2008) observed that the pollen grains of the genus Epilobium has both monad and tetrahedral tetrad structure.

\footnotetext{
* Corresponding author. Tel.: +0 4342220020

E-mail address: bbaser@beu.edu.tr

ORCID : 0000-0002-9305-8759 (B. Başer), 0000-0002-7367-9697 (N. Akay), 0000-0002-0861-4213 (M. Kürşat)
} 
Punt et al., (2003) and Makbul et al., (2008) determined that the pollen shape of the Epilobium taxon was suboblate or oblate and the pollen shape contributed significantly to the differentiation of the Epilobium taxon. Erdtman, 1960; Punt et al., 2003 revealed that there is a fine connection between the tetrad and monad pollen spreads by breaking this connection with the acetolysis method. Rahimi et al., (2018) determined that radial symmetrical, tetrahedral tetrad, trizonoporate, rugulate, granulate, verrucate, and striate ornamentations were observed in pollens and that these family members did not differ significantly in terms of characteristics such as pollen size, shape, and pore structure. Perveen and Qaiser (2013) determined that the pollen distribution of Epilobium is generally tetrahedral tetrad and rarely monad.

The aim of the study is to perform pollen morphology analyses of 11 different taxa belonging to Epilobium by using light and scanning electron microscopy methods and to clarify the usefulness of these features in terms of taxonomic implications.

\section{Materials and Methods}

Plant specimens was obtained from the specimens of Gazi University herberium (GAZI) and Bitlis Eren University Herbarium. The list of voucher specimens is deposited in GAZI and Bitlis Eren University Herberia.

\section{Specimens investigated.}

E. hirsutum L.: B8-Bitlis: Bitlis Agaçköprü Village and stream sides, 26.07.2013, 38 20'11.95" K, 42 00 10,88" D, 1350$1450 \mathrm{~m}$, M. Karataş 1304, Det.: M. Kurşat. E. parviflorum Schreb.: B8-Bitlis: Bitlis, Kambos Mountain north slope, 18.07.2014, 38 19' 23.26" K, 41ㅇ 59' 42.29" D, 1800-1950m, M. Karataş 2318, Det.: M. Kurşat. E. minutiflorum Hausskn.: B8-Bitlis: Bitlis, East of Mount Kambos, 18.06.2014, 38 ${ }^{\circ} 19^{\prime}$ 29.58" K, 4200' 33.33" D, 1400-1600 m, M. Karataş 2131, Det.: M. Kurşat. E. montanum L.: A4-Çankırı: Çankırı- Artacalar, Dumanlı Mountain, 1350 m, 05.07.1991 A. Duran 1236 (GAZI) E. confusum Hausskn.: B8-Bitlis: Bitlis, East of Mount Kambos, 18.06.2014, 38 $19^{\prime} 29.58 " \mathrm{~K}, 42^{\circ} 00^{\prime} 33.33^{\prime \prime} \mathrm{D}, 1400-1600 \mathrm{~m}$, M. Karataş 2088, Det.: M. Kurşat. E. ponticum Hausskn.: B8Bitlis: Bitlis, Mount Kambos south, 15.03.2014, 38 17' 52.83" K, 41 59' 15.31" D, 1240-1650m, M. Karataş 1553, Det.: M. Kurşat. E. gemmascens C.A.Mey.: B8-Bitlis: Bitlis, Kambos Mountain north slope 08.07.2013, 38 19' 23.26" K, 41 $59^{\prime}$ 42.29" D, 1800-1950m, M. Karataş 1188, Det: M. Kurşat. E. anagallidifolium Lam.: B8-Bitlis: Bitlis, Kambos Mountain north slope 03.07.2013, 38 19' 23.26" K, 41 59' 42.29" D, 1800-1950m, M. Karataş 1060, Det.: M. Kurşat. E. palustre L.: A8 Rize: Rize İkizdere, Başköy, 24.07.1984 A. Güner 6052 (GAZI). E. anatolicum Hausskn. subsp. anatolicum.: C6 Maraş: Maraş-Berit mountain, Karagöl, Yataz slope 2600 m, 25.07.1992 Z. Aytaç, 5531 (GAZI). E. anatolicum subsp. prionophyllum (Hausskn.) P.H.Raven: A8 Rize: Rize İkizdere, Başköy, 18.06.1986, A.Güner 6969 (GAZI).
For light microscopy (LM) analysis, The pollen grains were prepared for light (LM) and scanning microscopy (SEM) by the standard methods described by Wodehouse (1935). For light microscopy, the pollen grains were mounted in Safranin glycerin jelly and observations were made with a Olympus BX31 microscope under $(\mathrm{E} 40,0.65)$ and oil immersion (E100, 1.25), using 10x eye piece. Measurements were performed on at least 30 pollen grains per specimen for each morphological character (Polar axis (P), equatorial diameter (E), Plg (Porus length), Plt (porus width), mesoporium, apoporium, annulus length, annulus diameter, costae, exine and intine with LM using an oil immersion $100 \mathrm{U}$ objective lens.

For SEM studies, pollen grains were dried, mounted on stubs, coated with gold by sputter coaster, and the SEM examination was carried using a ZEISS Supra 55 Scanning Electron Microscope at the SEM Laboratory of the Central Research Laboratory (MERLAB), Yuzuncu Yil University, Van. In general, the terminology used is in accordance with Punt et al. (2007) and Hesse et al. (2009).

\section{Results}

The palynological properties of the examined Epilobium taxa are summarized in Table 1. Representative pollen grains are illustrated in Figures 1-3.

\subsection{Size, symmetry, and shape}

The pollen grains of the investigated species are dispersed as tetrad. They can be described as bilateral symmetrical and subisopolar based on SEM and LM observations. The shape of the pollen grains in equatorial view are suboblate, and oblatespheroidal, whilst their shape in polar view is triangular-obtus. The pollen grains of the genus are oblate-spheroidal, suboblate (E. anatolicum subsp. anatolicum, E. palustre, and E. confusum). The polar axis varies from $57.52-87.33 \mu \mathrm{m}$ and the equatorial diameters from 65.42-95.23 $\mu \mathrm{m}$. Amb diameter 62.50-92.74 $\mu \mathrm{m}$. Mesoporium (M) 36.78-62.08 $\mu \mathrm{m}$. Apoporium (Ap) 37.15$60.07 \mu \mathrm{m}$. Their dimensions are smaller in E. palustre and larger in E. hirsutum (Table 1; Figures 1-3).

\subsection{Apertures}

In the investigated taxa, there are eleven taxa with trizonoporate (rarely 2,4 porate), apertures at corners ( angulaaperturate) (Table 1). The porus is long (10.81-22.03 $\mu \mathrm{m})$ and broad (11.97-22.66 $\mu \mathrm{m})$; The shape of porus is circular. The apertural membrane is generally psilate and rarely granulate. Annulus thickness (An-th) 4.25-6.35 $\mu \mathrm{m}$. Annulus height (An-h) 14.29-23.58 $\mu \mathrm{m}$ (Table 1; Figures 1-3).

\subsection{Exine, intine and Ornamentations}

The exine ranges from 1.78 to $2.68 \mu \mathrm{m}$. Ectexine is thicker than endexine without costae and the intine is $0.39-0.69 \mu \mathrm{m}$ thick. The exine shows tumescence at the aperture. Costae thickness 
(C) 2.45-3.35 $\mu \mathrm{m}$. Exine sculpturing, showed three distinct types of surface structures: Baculate (the common type), baculate-rugulate (E. anatolicum subsp. prionophyllum), and rugulate (E.montanum) (Table 1; Figures 1-3).

Table 1. Summary of pollen morphological data for the Epilobium species examined.

\begin{tabular}{|c|c|c|c|c|c|c|c|}
\hline Taxa & $\mathbf{P}$ & $\bar{E}$ & $\mathbf{P} / \mathbf{E}$ & Plg & Plt & $\mathbf{E x}$ & In \\
\hline E. hirsutum & $87.33 \pm 11.09$ & $95.23 \pm 10.54$ & $\begin{array}{l}\text { Oblate- } \\
\text { spheroidal }\end{array}$ & $22.03 \pm 2.99$ & $22.66 \pm 2.67$ & $2.68 \pm 0.36$ & $0.66 \pm 0.18$ \\
\hline E. parviflorum & $72.03 \pm 5.95$ & $79.83 \pm 6.43$ & $\begin{array}{l}\text { Oblate- } \\
\text { spheroidal }\end{array}$ & $18.10 \pm 2.96$ & $17.57 \pm 2.85$ & $2.47 \pm 0.40$ & $0.45 \pm 0.17$ \\
\hline E. montanum & $82.52 \pm 3.09$ & $94.30 \pm 3.13$ & $\begin{array}{l}\text { Oblate- } \\
\text { spheroidal }\end{array}$ & $19.42 \pm 1.76$ & $19.58 \pm 1.95$ & $1.78 \pm 0.18$ & $0.56 \pm 0.11$ \\
\hline $\begin{array}{l}\text { E. anatolicum subsp. } \\
\text { anatolicum }\end{array}$ & $59.87 \pm 3.41$ & $67.45 \pm 2.46$ & Suboblate & $16.01 \pm 1.55$ & $15.97 \pm 1.20$ & $2.29 \pm 0.57$ & $0.63 \pm 0.17$ \\
\hline $\begin{array}{l}\text { E. anatolicum subsp. } \\
\text { prionophyllum }\end{array}$ & $73.73 \pm 4.23$ & $80.80 \pm 3.76$ & $\begin{array}{l}\text { Oblate- } \\
\text { spheroidal }\end{array}$ & $20.51 \pm 1.94$ & $22.23 \pm 2.64$ & $1.84 \pm 0.32$ & $0.50 \pm 0.14$ \\
\hline E. palustre & $57.52 \pm 3.48$ & $65.42 \pm 4.83$ & Suboblate & $10.81 \pm 1.33$ & $11.97 \pm 1.25$ & $2.14 \pm 0.43$ & $0.57 \pm 0.12$ \\
\hline E. minutiflorum & $63.17 \pm 7.85$ & $68.00 \pm 7.98$ & $\begin{array}{l}\text { Oblate- } \\
\text { spheroidal }\end{array}$ & $14.01 \pm 3.07$ & $14.40 \pm 2.50$ & $2.34 \pm 0.25$ & $0.39 \pm 0.13$ \\
\hline E. confusum & $68.17 \pm 4.50$ & $76.67 \pm 4.31$ & Suboblate & $16.30 \pm 1.99$ & $17.40 \pm 2.03$ & $2.10 \pm 0.22$ & $0.41 \pm 0.18$ \\
\hline E. ponticum & $71.23 \pm 4.69$ & $76.03 \pm 4.84$ & $\begin{array}{l}\text { Oblate- } \\
\text { spheroidal }\end{array}$ & $19.66 \pm 1.72$ & $20.33 \pm 1.49$ & $2.35 \pm 0.19$ & $0.69 \pm 0.16$ \\
\hline E. gemmascens & $79.86 \pm 7.84$ & $87.96 \pm 7.50$ & $\begin{array}{l}\text { Oblate- } \\
\text { spheroidal }\end{array}$ & $14.87 \pm 2.36$ & $16.77 \pm 2.35$ & $2.21 \pm 0.24$ & $0.51 \pm 0.15$ \\
\hline E. anagallidifolium & $67.20 \pm 2.34$ & $74.50 \pm 2.69$ & $\begin{array}{l}\text { Oblate- } \\
\text { spheroidal }\end{array}$ & $14.60 \pm 1.10$ & $14.43 \pm 1.25$ & $2.30 \pm 0.33$ & $0.54 \pm 0.09$ \\
\hline
\end{tabular}

\begin{tabular}{|l|l|l|l|l|l|l|l|}
\hline Taxa & An-th & An. h. & Amb & M & Ap & C & Orn. \\
\hline E. hirsutum & $4.61 \pm 0.90$ & $21.49 \pm 2.01$ & $90.09 \pm 6.54$ & $61.86 \pm 3.73$ & $59.40 \pm 1.42$ & $2.49 \pm 0.48$ & Baculate \\
\hline E. parviflorum & $4.98 \pm 0.71$ & $18.93 \pm 1.34$ & $83.92 \pm 5.83$ & $46.41 \pm 2.38$ & $48.10 \pm 0.92$ & $3.25 \pm 0.26$ & Baculate \\
\hline E. montanum & $6.13 \pm 0.52$ & $20.39 \pm 2.01$ & $92.74 \pm 4.12$ & $62.08 \pm 3.24$ & $60.07 \pm 1.27$ & $3.35 \pm 0.46$ & Rugulate \\
\hline $\begin{array}{l}\text { E. anatolicum subsp. } \\
\text { anatolicum }\end{array}$ & $5.54 \pm 0.72$ & $16.56 \pm 1.26$ & $65.75 \pm 2.75$ & $36.78 \pm 2.09$ & $37.15 \pm 0.90$ & $3.11 \pm 0.52$ & Baculate \\
\hline $\begin{array}{l}\text { E. anatolicum subsp. } \\
\text { prionophyllum }\end{array}$ & $6.35 \pm 1.01$ & $18.29 \pm 1.73$ & $84.50 \pm 5.57$ & $46.52 \pm 1.98$ & $48.42 \pm 2.43$ & $2.87 \pm 0.45$ & $\begin{array}{l}\text { Baculate- } \\
\text { rugulate }\end{array}$ \\
\hline E. palustre & $5.84 \pm 0.70$ & $14.29 \pm 1.20$ & $62.50 \pm 5.30$ & $37.14 \pm 0.78$ & $39.02 \pm 0.94$ & $2.65 \pm 0.46$ & Baculate \\
\hline E. minutiflorum & $5.27 \pm 1.39$ & $15.48 \pm 2.48$ & $70.36 \pm 5.30$ & $43.07 \pm 1.18$ & $44.82 \pm 2.34$ & $2.79 \pm 0.58$ & Baculate \\
\hline E. confusum & $4.98 \pm 0.82$ & $17.69 \pm 1.13$ & $78.19 \pm 3.77$ & $40.24 \pm 0.62$ & $41.43 \pm 3.08$ & $2.55 \pm 0.20$ & Baculate \\
\hline E. ponticum & $4.25 \pm 1.04$ & $20.28 \pm 0.98$ & $77.42 \pm 4.17$ & $50.72 \pm 1.08$ & $48.43 \pm 2.66$ & $2.45 \pm 0.31$ & Baculate \\
\hline E. gemmascens & $6.01 \pm 0.74$ & $23.58 \pm 1.01$ & $89.24 \pm 3.29$ & $55.08 \pm 2.03$ & $56.73 \pm 1.99$ & $2.72 \pm 0.54$ & $\begin{array}{l}\text { Baculate- } \\
\text { rugulate }\end{array}$ \\
\hline E. anagallidifolium & $4.50 \pm 0.62$ & $20.25 \pm 1.40$ & $72.02 \pm 2.94$ & $50.72 \pm 1.08$ & $53.01 \pm 1.08$ & $2.75 \pm 0.63$ & Baculate \\
\hline
\end{tabular}




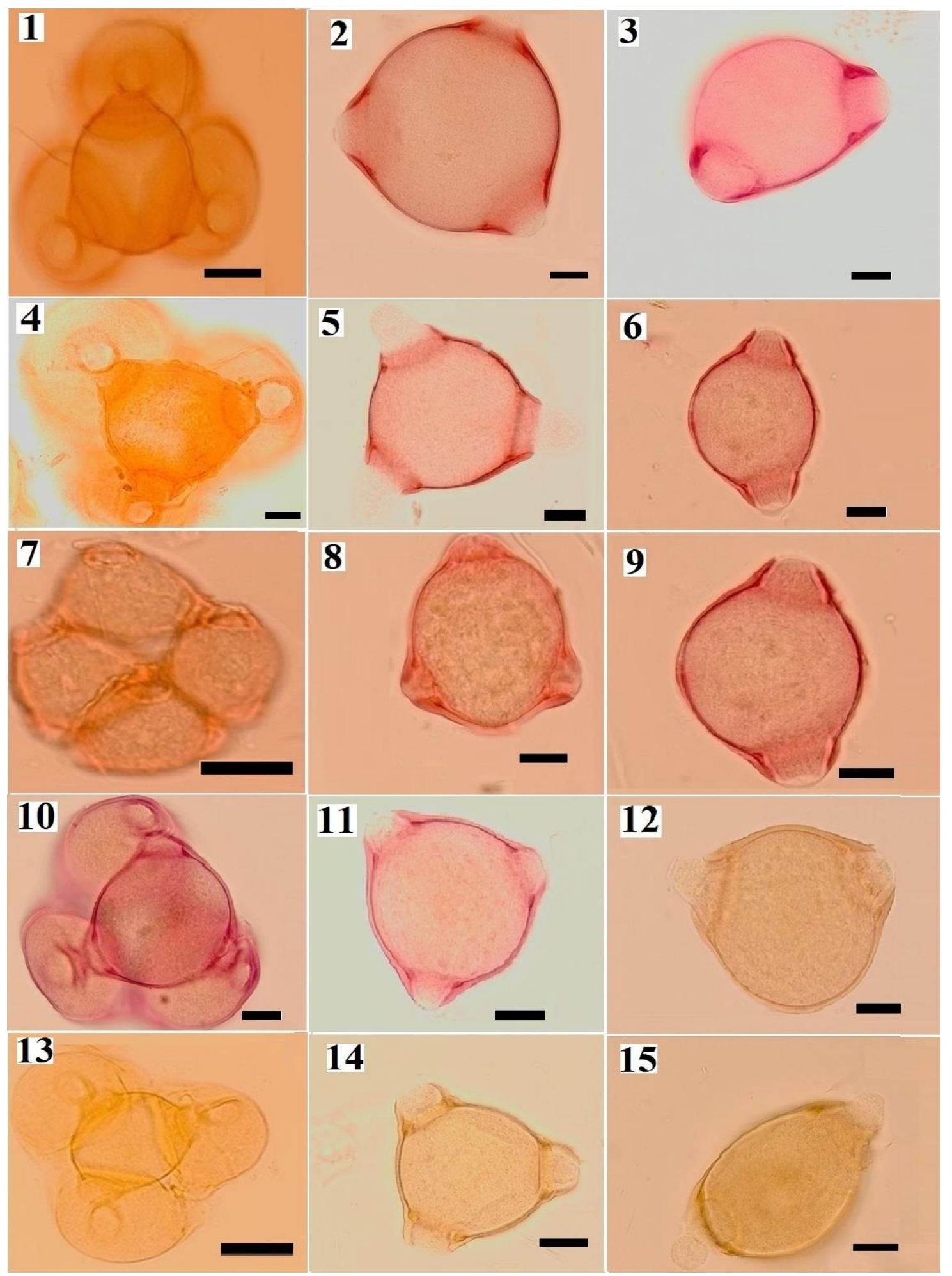

Figure 1. Pollen grains LM photos of studied taxa: tetrad, polar and equatorial view respectively; (1-3) Epilobium hirsutum, (4-6) E. parviflorum, (7-9) E. montanum, (10-12) E. anatolicum subsp. anatolicum, (13-15) E. anatolicum subsp. prionophyllum $($ Scale bar $20 \mu \mathrm{m})$ and $(\mathbf{1 , 7 , 1 3} ; \mathrm{Scale}$ bar $50 \mu \mathrm{m})$. 


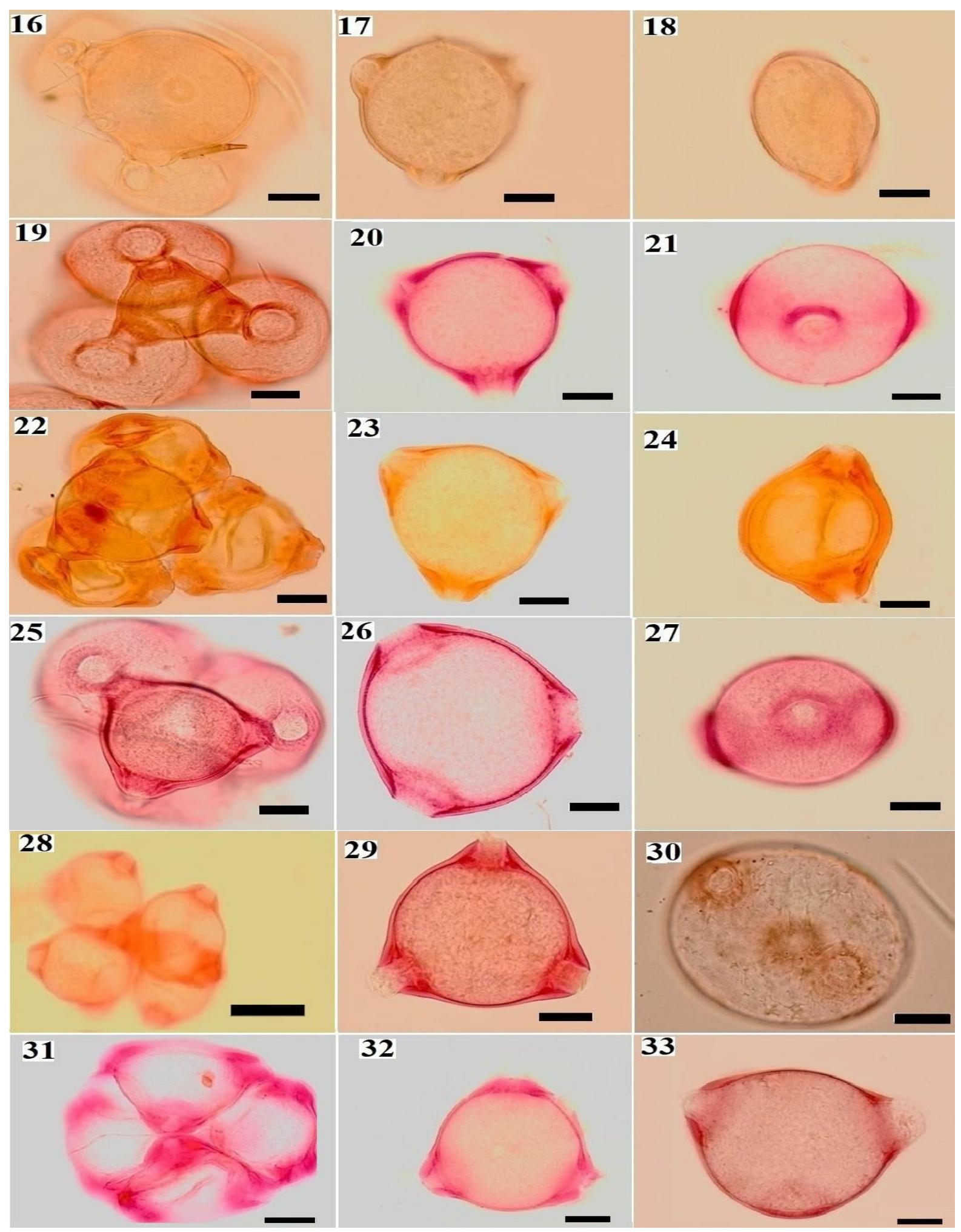

Figure 1. (Continued) (19-21) E. minutiflorum, (22-24) E. confusum, (25-27) E. ponticum, (28-30) E. gemmascens, (31-33) E. anagallidifolium (Scale bar $20 \mu \mathrm{m}$ ) and (28; Scale bar $50 \mu \mathrm{m})$. 


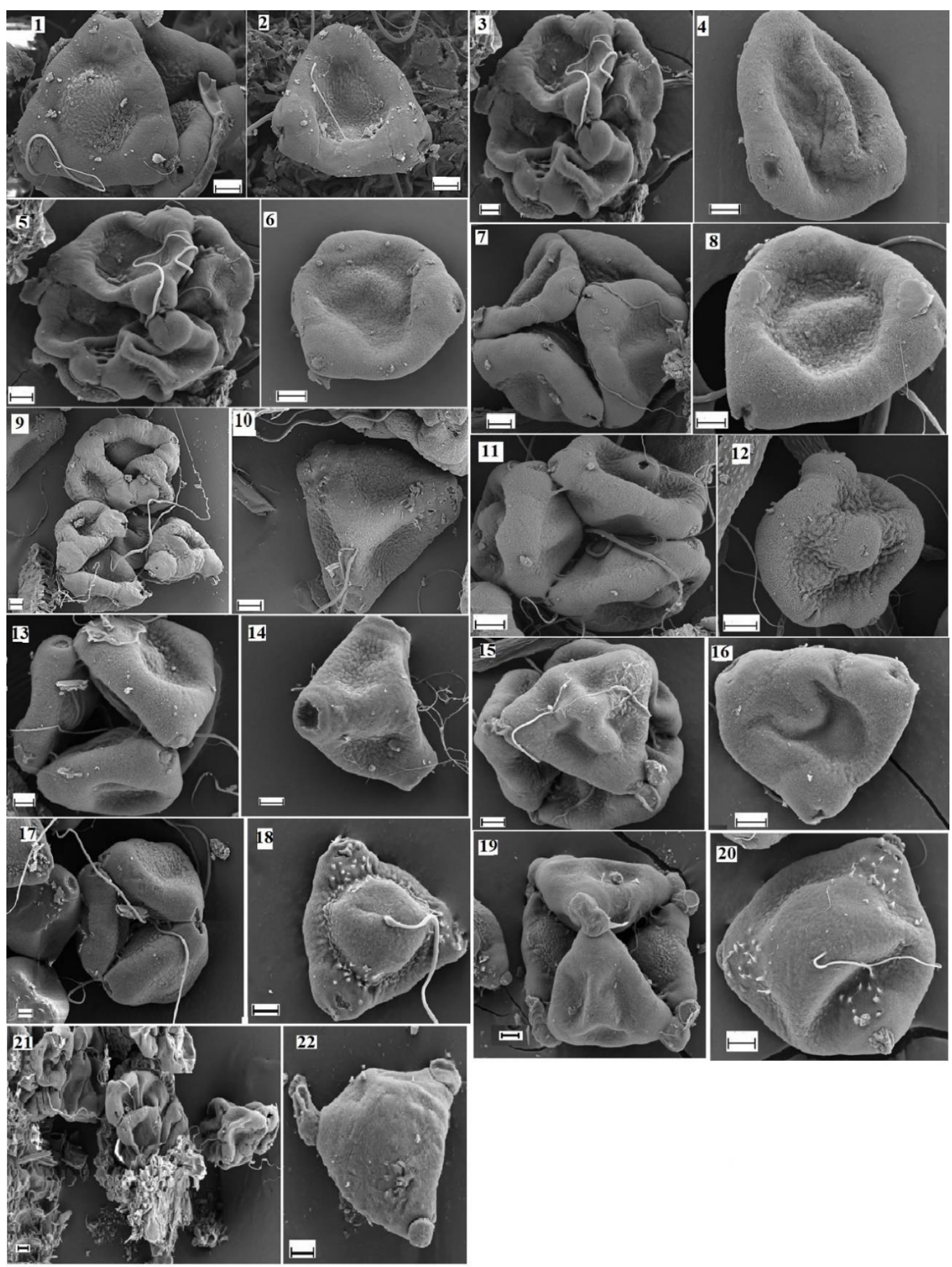

Figure 2. Pollen grains SEM photos of studied taxa: tetrad and general view respectively; (1-2) Epilobium hirsutum, (3-4) E. parviflorum, (5-6) E. montanum, (7-8) E. anatolicum subsp. anatolicum, (9-10) E. anatolicum subsp. prionophyllum, (11-12) E. palustre, (13-14) E. minutiflorum, (1516) E. confusum, (17-18) E. ponticum, (19-20) E. gemmascens, (21-22) E. anagallidifolium (Scale bar 5 $\mu \mathrm{m})$. 


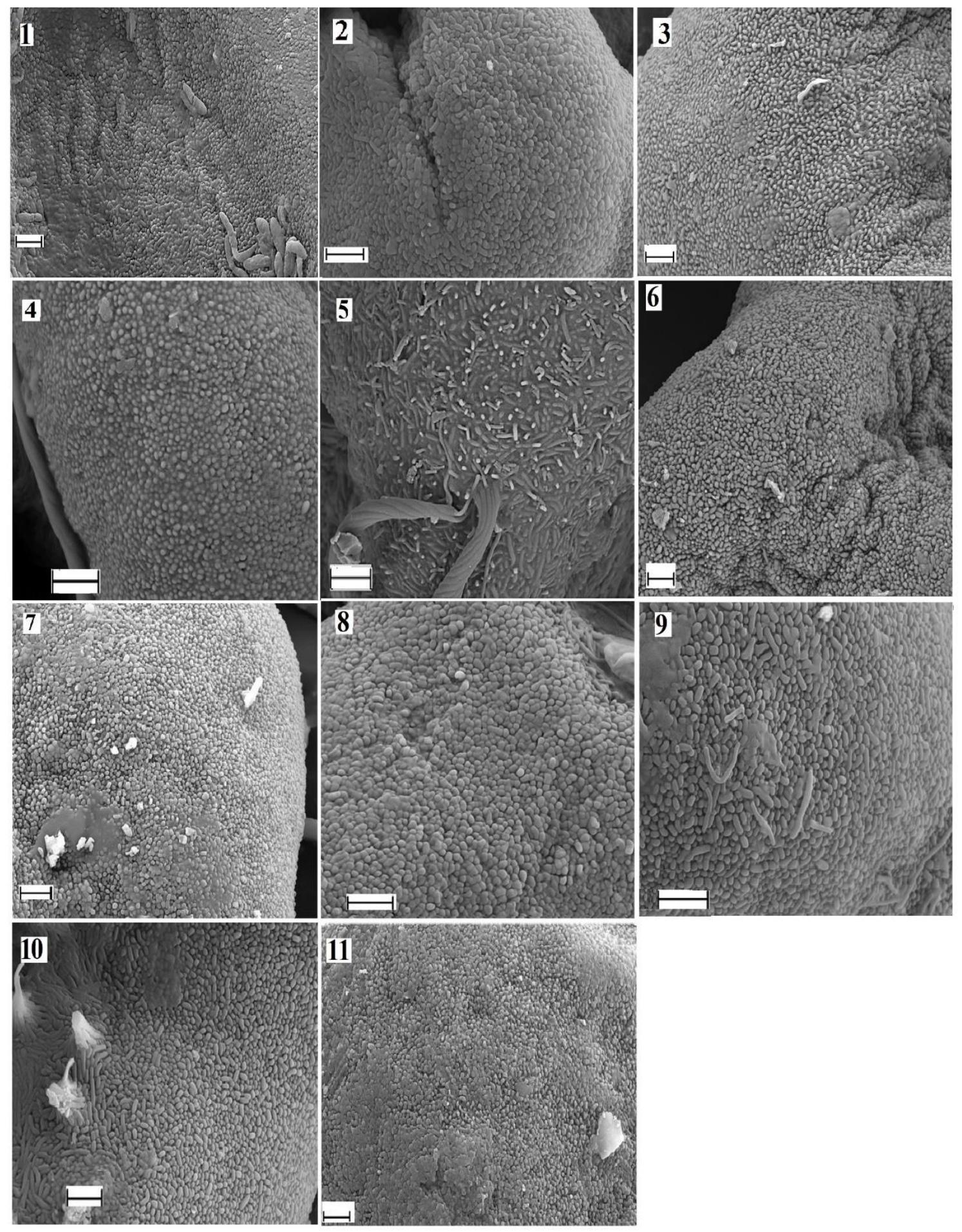

Figure 3. Pollen grains SEM photos of studied taxa: ornamentation; (1) Epilobium hirsutum, (2) E. parviflorum, (3) E. montanum, (4) E. anatolicum subsp. anatolicum, (5) E. anatolicum subsp. prionophyllum, (6) E. palustre, (7) E. minutiflorum, (8) E. confusum, (9) E. ponticum, (10) E. gemmascens, (11) E. anagallidifolium (Scale bar $2 \mu \mathrm{m}$ ). 


\section{Discussion}

Pollen grains characteristics of Epilobium 11 taxa are summarised in Table 1 and are shown in Figs. 1-3. Pollen grains are are tetrad, apertures (angulaperturate) at corners and pollen grains are triangular-obtus, 3-zonoporate $(E$. anatolicum susbsp. anatolicum $4 \% 2$-porate, E. anatolicum subsp. prionophyllum taxa, $3 \% 2$-porate and $6 \% 4$-porate and E. palustre $6 \%$ 4-porate). E. montanum, E. anatolicum subsp. anatolicum, E. palustre, E. confusum taxa have suboblate and other taxa have oblate-spheroidal pollen grains shape. E. palustre $(57.52 \mu \mathrm{m}$ and $65.42 \mu \mathrm{m})$ with the smallest polar axis and equatorial axis has the largest polar axis E. hirsutum (87.33 $\mu \mathrm{m}$ and $95.23 \mu \mathrm{m})$. The taxon with the smallest pore length and pore width is E. palustre $(10.81 \mu \mathrm{m}$ and $11.97 \mu \mathrm{m})$. The largest polar axis is E. hirsutum $(22.03 \mu \mathrm{m}$ and $22.66 \mu \mathrm{m})$. The smallest exine thickness is in E. montanum $(1.78 \mu \mathrm{m})$ and the largest one is in E. hirsutum $(2.68 \mu \mathrm{m})$. The smallest intin thickness is observed in the taxon E. minutiflorum $(0.39 \mu \mathrm{m})$, while the largest thickness is observed in the taxon E. ponticum $(0.69$ $\mu \mathrm{m})$. E. ponticum $(4.25 \mu \mathrm{m})$ has the smallest annulus thickness, and E. anatolicum subsp. prionophyllum $(6.35 \mu \mathrm{m})$ has the greatest thickness. E. palustre $(14.29 \mu \mathrm{m})$ has the shortest annulus height and E. anatolicum subsp. prionophyllum $(23.58$ $\mu \mathrm{m})$ has the largest taxon. The smallest ambi diameter is in E. palustre $(62.50 \mu \mathrm{m})$, and the largest in E. montanum (92.74 $\mu \mathrm{m})$. The shortest mesoporium is in E. anatolicum subsp. stated that pollen grains color can also be used for species differentiation from the genus Clarkia Pursh in Onagraceae.

Skvarla et al. (2008) reported that pollens with tetrahedral tetrad characteristics in Onagraceae are connected to each other by bridges and that the structures called viscin threads formed in tetrahedral pollens. This is also characteristic for Epilobium taxa which are the structures that connect the pollen. It was also noted that the palynolomorphological characters have taxonomic importance and the importance of more detailed studies in order to obtain more effective results was emphasized in the study.

Punt et al. (2003) determined 7 different pollen types according to micromorphological features such as pollen grain size, aperture type and exine thickness in the Northwest European Epilobium. In this genus, three different types of pollen: Epilobium angustifolium-type, E. latifolium-type and E. tetragonum-type were included. The structure of pollen is radial symmetrical, monad and tetrad. Tectum characteristic is pitted-angular, fine granular, rod-like, oblate, suboblate andspheroidal pollen. Their shapes revealed that they have granulate and striate-rugulate ornamentation.

Makbul et al. (2008) revealed that Epilobium palustre, E. algidum Bieb., E. ponticum, E. confusum E. hirsutum, E. montanum pollen grains are radially symmetrical, isopolar, 3zonoporate and generally shed in monads, rarely tetrads. Pollen grains shape are suboblate, E. montanum (spheroidal). taxa of Epilobium are usually tetrahedral tetrads and rarely monads. In the examination carried out on a certain number of anatolicum $(37.15 \mu \mathrm{m})$, and the largest one is in E. montanum $(62.08 \mu \mathrm{m})$. Apoporium is seen in the shortest taxon $E$. anatolicum subsp. anatolicum $(37.15 \mu \mathrm{m})$, and the largest in $E$. montanum $(60.07 \mu \mathrm{m})$. The taxon with the smallest costal thickness is E. ponticum $(2.45 \mu \mathrm{m})$, and the largest one is $E$. montanum $(3.35 \mu \mathrm{m})$. It was determined that the taxon $E$. montanum has rugulate, E. anatolicum subsp. prionophyllum and E. gemmascens baculate-rugulate, while the other taxa have baculate ornamentation.

Some studies on the palynomorphological features of Epilobium genera have been carried out (Chen and Wang, 2001; Punt et al., 2003; Skvarla et al., 2008; Perveen and Qaiser, 2013). The most comprehensive palynological studies on Epilobium taxa in our country were made by Makbul et al. (2008); Okur (2019). Makbul et al. (2008) revealed the morphological features of the pollen of Epilobium 6 taxon and stated that all species of our country should be studied in order to make more contribution. (Patel et al., 1984; Perveen and Qaiser, 2013; Okur, 2019) determined that the pollen distribution of Epilobium is generally tetrahedral tetrad and rarely monad.

Lewis and Lewis (1955) reported that in addition to morphological features such as umb diameter, pore size, exine and ectexin thickness of pollen, the color of fresh pollen is effective in the differentiation of taxa, and Small et al., 1971

The outline is triangular in meridional optical section. Polar axis is $78-67 \mu \mathrm{m}$ and equatorial axis is $87-94 \mu \mathrm{m}$. The aperture membrane is generally psilate and rarely granulate. The exine is tectate. Ornamentation is baculate, E. ponticum and E. confusum (striate). They stated that palynological characters such as pollen shape and surface ornamentation were effective in distinguishing Epilobium taxa.

Perveen and Qaiser (2013) found that the tectum structure of pollen grains belonging to the Onagraceae is an important characteristic. Rugulate-perforate ornamentation was observed in two Oenothera species (O. affinis Combess. and $O$. glazioviana Michel), which are known for their taxonomic affinity to the genus Epilobium, while Epilobium leiophyllum Haussn. It has been determined that it has a granulate ornamental structure, as well as E. angustifolium, E. cylindricum D.Don., E. hirsutum, E. latifolium L., E. parviflorum and E. palustre species with scabrate ornamentation.

Erdtman 1960; Punt et al. 2003 revealed that there is a fine connection between the tetrad and monad pollen grains spreads by breaking this connection in the acetolysis process. Skvarla et al. (2008) observed that the pollen of the genus Epilobium has both monad and tetrahedral tetrad structures. They revealed that the monad structure, the tetrahedral tetrad structure, was formed as a result of the breakdown of the bridges between pollens and each other during the preparation process. Makbul et al. (2008) observed that the pollens of the 6 taxa, it was determined that the pollen grains in the monad structure supported the stated idea. 
As a result of their examination on the pollens of the genus Epilobium, Okur et al. (2019), stated that the pollen is monad or tetrahedral or, bilateral, with subisopolar symmetry, 3porat (trizonoporate). Surface ornamentation is baculate, striate and baculate-rugulate. They determined that the pollen grains in the Epilobium section spread in tetrahedral form from the anther and monad in the Chamaenerion section. They determined that the pollen shape of the taxa belonging to Epilobium, exine ornamentation, and pollen grains leaving the anther, ie spreading (pollen out of the anther monate or tetrahedral) are important in the differentiation of pollen. Okur (2019) determined that Epilobium and Chamaenerion taxa have baculate, baculate-rugulate, rugulate, baculate-pliate ornaments and pollen grains size is between 40.70-53.96 $\mu \mathrm{m}$. They determined that it may be due to the fact that they have carried out palynolomorphological studies on the taxon.

Our results and the data of Okur 2019 were found to be compliant regarding the fact that the taxa are tetrahedral tetrads and ornamentations with trizonoporate (E. anatolicum susbsp. anatolicum 4\% 2-porate, E. anatolicum subsp. prionophyllum taxa, 3\% 2-porate and 6\% 4-porate and E. palustre 6\% 4-porate) pollens were observed. On the other hand, using different methods may have caused differences in the polar and equatorial axis, pore length and width, exine and intin thickness, annulus thickness, Amb diameter, mesoporium and apoporium thicknesses.

Epilobium is considered to be a taxonomically difficult genus due to the fact that it contains a large number of taxa with morphological similarities and the high percentage of hybridization within the genus (Krajsek et al., 2006). For this reason, it is emphasized that making a distinction only on morphological characters is not a solution in the differentiation of taxa belonging to the genus and there is a need for various studies that will contribute to this distinction.

In our opinion, revealing the morphological features of the pollen of 11 taxa belonging to Epilobium will contribute primarily to plant systematics and other fields of palynology.

\section{Acknowledgements}

We wish to thank Curators of Herbaria GAZI and Bitlis Eren University Herbaria, who allowed us to study their Epilobium specimens, to Dr. Yüksel AKINAY and Dr. Ihsan Nuri AKKUŞ (Science Application and Research Center, University of Yuzuncu Yil, Van) who is helper to take of electron photographs of pollen grains surface.

\section{References}

Brown, D.D., 1967. Chapter 2. The Genes for Ribosomal RNA and their Transcription During Amphibian Development, Current Topics in Developmental Biology, 2: 47-73.
Chen, S.H., Wang, Y.F., 2001. Pollen Flora of Yuenyang Lake Nature Preserve, Taiwan (II), Taiwania, 46 (2): 167-191.

Erdtman, G., 1952. Pollen Morphology and Plant Taxonomy, Almqvist and Wiksells, 133-134.

Erdtman, G., 1960. The acetolysis method. A revised description. Svensk Botanisk, Tidskrift, 54: 561-564.

Graham, A., Barker, G. \& Da Silva, M.F., 1980. Unique pollen types in the Caesalpinioideae (Leguminosae). Grana, 19: 79-84.

Hesse, M., Halbritter, H., Zetter, R., Weber, M., Buchner, R., Frosch Radivo, A., \& Ulrich, S., 2009. Pollen terminology an illustrated handbook. -Spri. Verlag. Vienna.

Heywood, V.H., Brummitt, R.K., Culham, A. and Seberg, O., 2007. Flowering Plant Families of the World. Royal Botanic Gardens, Kew. 1- 424.

Keri, C. \& Zetter, R., 1992. Notes on the exine ultrastructure of Onagraceae and Rhododendroideae (Ericaceae). -Grana, 31: 119-123.

Krajsek, S.S., Dermastia, M. and Jogan, N., 2006. Determination key for Central European Epilobium species based on trichome morphology. Botanica Helvetica, 116: 169-178.

Lewis, H. and Lewis, M.E., 1955. The genus Clarkia. University of California Publications in Botany, 20: 241-392.

Makbul, S., Türkmen, Z., Coskuncelebi, K. \& Beyazoglu, O., 2008. Anatomical and pollen characters in the genus Epilobium L. (Onagraceae) from Northeast Anatolia. Acta. Biol. Cracov. Bot. 50: 51-62.

Mitroiu, N., 1963. Certetari palinologice aspura microsporilordon familia Onagraceae. Acta Botanica Horti Bucuresti. 1: 435-457.

Mosquin, T., 1966. A new taxonomy for Epilobium angustifolium L. Brittonia 18: 167-188.

Okur, S., 2019. Türkiye Epilobium L. (Onagraceae) Taksonlarının Biyosistematik Yönden İncelenmesi. Recep Tayyip Erdoğan Üniversitesi, Fen Bilimleri Enstitüsü. Doktora Tezi. 1-262.

Punt, W., Rovers, J. and Hoen, P.P., 2003. The Northwest European Pollen Flora, Onagraceae, 67. Review of Palaeobotany and Palynology, 123: 107-161.

Praglowski, J., Nowicke, J.W., Skvarla, J.J., Hoch, P.C., Raven, P.H. \& Takahashi, M., 1994. Onagraceae Juss.: Circaeeae DC., Hauyeae Raimann, Epilobieae Spach. World Pollen and Spore Flora 19: 1-38.

Patel, V.C., Skvarla, J.J. and Raven, P.H., 1984. Pollen characters in relation to the delimitation of Myrtales. Annals of the Missouri Botanical Garden, 71: 858-96.

Perveen, A. and Qaiser, M., 2013. Pollen Flora of Pakistan-LXXI. Onagraceae. Pakistan Journal of Botany, 45(1): 241-245.

Punt, W., Hoen, P.P., Blackmore, S., Nilsson, S. and Le Thomas, A., 2007. Glossary of pollen and spore terminology. Review of Palaeobotany and Palynology, 143, 1-81.

Rahimi, S., Mehrabian, A.R., Sheidai, M. and Sadr, M.M., 2018. Pollen morphology of Onagraceae in Iran. Iranian Journal of Botany, 24 (1): 16-27.

Raven, P.H., 1962a. The genus Epilobium in Turkey. Notes from the Royal Botanic Garden Edinburgh, 24: 183-203. 
Rowley, J. \& Claugher, D., 1996. Structure of the exine of Epilobium angustifolium (Onagraceae). Grana. 35: 79-86.

Rowley, J.R., \& Skvarla. J.J., 2006. Pollen development in Epilobium (Onagraceae): Late microspore stages (a review). -Rev. Palaeobot. Palynol. 140: 91-112.

Skvarla, J.J., Chissoe, W.F. and Sharp, M., 1978. An ultrastructural study of viscin threads in Onagraceae pollen. Pollen et Spores, 20: 5-143.

Skvarla, J.J., Rowley, J.R., Hoch, P.C. and Chissoe, W.F., 2008. Unique tetrads of Epilobium luteum (Onagraceae: Onagreae) pollen from Alaska. Brittonia, 60: 398-404.

Small, E., Bassett I.J., Crompton, C.W. and Lewis, H., 1971. Pollen phylogeny in Clarkia Taxon, 20: 739-746.

Ting, W.S., 1966. Pollen morphology of Onagraceae. Pollen et Spores, 8: 9-36.
Wagner, W.L., Hoch, P.C., Raven, P.H., 2007. Revised Classification of the Onagraceae. Syst. Bot. Monogr., 83: 1239.

Walter, B., Ulf, S., Michael, R., 2007. Interspecific hybridization between alien and native plant species in Germany and its consequences for native biodiversity. Biol. Conserv. 137: 248-253.

Wodehouse, R.P., 1935. Pollen Grains: Their Structure, Identification and Significance in Science and Medicine. Hafner Publish, Company, New York \& London, pp. 106109. 